\title{
17 $\beta$-Estradiol Prevents Early-Stage Atherosclerosis in Estrogen Receptor-Alpha Deficient Female Mice
}

\author{
Amparo C. Villablanca - Amy Tenwolde - Michael Lee • \\ Melissa Huck • Shannon Mumenthaler • \\ John C. Rutledge
}

Received: 14 February 2009 / Accepted: 17 April 2009 /Published online: 2 May 2009

(C) The Author(s) 2009. This article is published with open access at Springerlink.com

\begin{abstract}
Estrogen is atheroprotective and a high-affinity ligand for both known estrogen receptors, $\mathrm{ER} \alpha$ and $\mathrm{ER} \beta$. However, the role of the ER $\alpha$ in early-stage atherosclerosis has not been directly investigated and is incompletely understood. ER $\alpha$-deficient $(\mathrm{ER} \alpha-/-)$ and wild-type $(\mathrm{ER} \alpha+/+)$ female mice consuming an atherogenic diet were studied concurrent with estrogen replacement to distinguish the actions of $17 \beta$-estradiol $\left(E_{2}\right)$ from those of $E R \alpha$ on the development of early atherosclerotic lesions. Mice were ovariectomized and implanted with subcutaneous slowrelease pellets designed to deliver 6 or $8 \mu \mathrm{g} /$ day of exogenous $17 \beta$-estradiol $\left(E_{2}\right)$ for a period of up to 4 months. Ovariectomized mice (OVX) with placebo pellets ( $E_{2}$-deficient controls) were compared to mice with endogenous $E_{2}$ (intact ovaries) and exogenous $E_{2}$. Aortas were analyzed for lesion area, number, and distribution. Lipid and hormone levels were also determined. Compared to OVX, early lesion development was significantly $(p<0.001)$ attenuated by $E_{2}$ with $55-64 \%$ reduction in lesion area by endogenous $E_{2}$ and $>90 \%$ reduction by exogenous $E_{2}$. Compared to OVX, a decline in lesion number (2- to
\end{abstract}

A. C. Villablanca J. C. Rutledge

Department of Internal Medicine, University of California, Davis, Davis, CA, USA

A. Tenwolde $\cdot$ M. Lee $\cdot$ M. Huck $\cdot$ S. Mumenthaler Center for Comparative Medicine, University of California, Davis,

Davis, CA, USA

A. C. Villablanca $(\bowtie)$

Division of Cardiovascular Medicine, University of California, Davis,

One Shields Ave., TB 172,

Davis, CA 95616-8636, USA

e-mail: avillablanca@ucdavis.edu 4-fold) and lesser predilection ( 4-fold) of lesion formation in the proximal aorta also occurred with $\mathrm{E}_{2}$. Lesion size, development, number, and distribution inversely correlated with circulating plasma $\mathrm{E}_{2}$ levels. However, atheroprotection was independent of $\mathrm{ER} \alpha$ status, and $\mathrm{E}_{2}$ atheroprotection in both genotypes was not explained by changes in plasma lipid levels (total cholesterol, triglyceride, and high-density lipoprotein cholesterol). The $\mathrm{ER} \alpha$ is not essential for endogenous/exogenous $E_{2}$-mediated protection against early-stage atherosclerosis. These observations have potentially significant implications for understanding the molecular and cellular mechanisms and timing of estrogen action in different estrogen receptor (ER) deletion murine models of atherosclerosis, as well as implications to human studies of ER polymorphisms and lipid metabolism. Our findings may contribute to future improved clinical decisionmaking concerning the use of hormone therapy.

Keywords Estrogen - Vascular Hormone - Lipid ·

Atherosclerosis

\section{Introduction}

Coronary heart disease is relatively rare in premenopausal women compared to postmenopausal women or men. After menopause, the sex protection in women decreases, and cardiovascular risk parameters are adversely impacted [1]. Pathogenic consequences of menopause and sex differences in disease prevalence are attributed to differences in estrogen levels supplied to cardiovascular tissues. Estradiol (17 $\beta$-estradiol, $\mathrm{E}_{2}$ ) atheroprotection has been documented in many animal models of atherosclerosis [25], including murine models with targeted mutations (reviewed in [6]). 
In humans, observational epidemiological studies strongly support an atheroprotective role for endogenous $E_{2}$ [7], largely attributed to reductions in low-density lipoprotein (LDL) and increases in high-density lipoprotein (HDL) cholesterol [8,9], antioxidant actions [10, 11], and a direct biological effect on cardiovascular tissue [12-14]. In contrast, clinical trials have failed to confirm the benefits of combined or unopposed estrogen reported by earlier observational studies [15-17]. The hypothesis that hormone therapy is an effective preventive measure for coronary heart disease has been challenged by these trials, perhaps in part due to the inclusion of postmenopausal women with subclinical coronary artery plaque. The weight of the evidence indicates that older women and those with subclinical or overt coronary heart disease should not take hormone therapy. However, timing of initiation of hormone therapy in relation to menopause onset and age might reduce coronary risk over time, presumably by affording atheroprotection prior to the onset of established vascular disease [18]. In addition, factors including the method of administration, dose, and duration of use of exogenous hormone may also be relevant. Nonetheless, the overall clinical utility of hormone therapy for atheroprevention remains controversial and complex.

Estrogen's long-term effects are generally ascribed to transcriptional modulation of target genes through estrogen receptors (ERs) [19]. Two ERs, ER $\alpha$ (ESR1) and ER $\beta$ (ESR2), have been characterized [20, 21]. They are encoded on two separate genes (ESR1 and ESR2), are distinct functionally and structurally, and have overlapping though not identical tissue expression patterns [21-23]. Functional estrogen receptors are expressed in vascular endothelial cells [24], smooth muscle cells [25, 26], and macrophages [27]. Normal coronary arteries of premenopausal women demonstrate normal ER expression, whereas in atherosclerotic vessels of postmenopausal women, ERs are downregulated [28]. Thus, changes in expression of ERs accompany atherogenesis, though the direction and magnitude of the association needs clarification.

In humans and rodents, both ERs may mediate protection against vascular injury [25, 29]. However, the individual contribution of sex steroid hormones and their cognate receptors to the atherosclerosis and its progression remains poorly understood. In LDL-receptor (LDL-R) and apolipoprotein (Apo) E-deficient mice, $\mathrm{ER} \alpha$ is a major mediator of $E_{2}$ 's atheroprotective effects on advanced atherosclerotic lesions [30-33]. However, studies to distinguish the atheroprotective effects of $E_{2}$ from those of $E R \alpha$ in the development of early atherosclerosis and examine the mechanism of $E_{2}$ protection in fatty-steak formation are limited. In comparing the effects of $\mathrm{E}_{2}$ treatment on spontaneous development of atherosclerotic lesions in ApoE-/- mice (with or without the ER $\alpha$ ), the major atheroprotective effect of $\mathrm{E}_{2}$ was substantially abrogated in mice lacking both ApoE and ER $\alpha$ [33]. However, some of the protective effects of $E_{2}$ appeared to be $E R \alpha$ independent.

Thus, there is continued need to define the individual contribution(s) of estrogen and estrogen receptors to atherosclerosis, the stage(s) of atherosclerosis when estrogen is atheroprotective, and the stage-specific mechanism (s) involved in vasculoprotection. The goal of this study was to directly examine the action of the $\operatorname{ER} \alpha$ in $E_{2}$ mediated atheroprotection, using a murine model of earlystage atherosclerosis (fatty streaks) deficient for the $\operatorname{ER} \alpha$, in order to directly examine the action of the ER $\alpha$ in early $E_{2}-$ mediated atheroprotection, identify the individual contribution(s) of estrogen and/or the ER $\alpha$ to early atherogenesis, and address mechanisms of $\mathrm{E}_{2}$ protection in early vascular disease. The study design permitted us to evaluate three potential individual and/or interrelated mechanisms for atheroprotection in early-onset disease: [1] $17 \beta$-estradiol $\left(E_{2}\right),[2]$ the estrogen receptor-alpha $(E R \alpha)$, and [3] serum lipids.

\section{Materials and Methods}

All experiments were performed in compliance with the National Institutes of Health (NIH) Guidelines and in accordance with protocols approved by the Animal Care and Use Committee of the University of California, Davis.

Generation and Use of Mice Mice heterozygous for the $\mathrm{ER} \alpha$ gene $(\mathrm{ER} \alpha+/-)$, obtained from Dr. Dennis Lubahn (University of Missouri) and mated to yield a breeding colony and progeny lacking the $\operatorname{ER} \alpha$ gene $(\mathrm{ER} \alpha-/-)$, and wild-type littermate controls having intact $\operatorname{ER} \alpha(\operatorname{ER} \alpha+/+)$ were used. The correct genotype was confirmed by polymerase chain reaction (PCR) amplification of genomic DNA. Tail DNA from progeny of heterozygous matings was genotyped as previously described [34] using DNeasy spin columns (Qiagen kit) per the manufacturer's instructions. PCR amplification was used to distinguish homozygous mutants from heterozygotes and wild-type animals. Primers used to amplify products specific for the wild-type gene and disrupted ER $\alpha$ gene were synthesized as custom primers (Life Technologies). Primer sequences for presence of the targeted $\mathrm{ER} \alpha$ gene in homozygous mutants (a 649-bp fragment only) and animals with the normal wild-type gene (a 239-bp fragment only) were as follows:

ER $\alpha-/-(\mathrm{KO})$ forward 5' TGAATGAACTGCAG GACGAG 3' and reverse 5' AATATCACGGGTAGC CAACG 3' 
$\mathrm{ER} \alpha+/+$ (WT) forward 5' CTACGGCCAGTCGGG CAT $3^{\prime}$ and reverse $5^{\prime}$ AGACCTGTAGAAGGCGG GAG 3'

Mice were housed in a temperature-, $12 \mathrm{~h}$ light-, and humidity-controlled environment in a dedicated pathogenfree barrier facility at the University of California, Davis. $\mathrm{ER} \alpha$ gene deletion mice have a mixed genetic background from strains 129/J and C57BL/6 J, an atherosclerosissusceptible strain. They are infertile but otherwise phenotypically normal [34]. They do not produce a fully functional $\mathrm{ER} \alpha$ and have no demonstrable full-length wild-type ER $\alpha$ protein [34]. However, the disrupting neosequence used to generate the knockout results in a variant $\mathrm{ER} \alpha$ protein (not the full-length $\mathrm{ER} \alpha$ wild-type protein) contained an internal deletion of a portion of the N-terminal region of the receptor. This alternative $\mathrm{ER} \alpha$ protein has residual low-level, high-affinity, estradiol-binding activity $[35,36]$ but, importantly, lacks the specificity to be from either ER $\alpha$ or ER $\beta$ (Liu and Lubahn, unpublished data).

Atherogenesis Model and Experimental Design Experimental animals were weaned at 4 weeks. To manipulate estrogen status, age-matched ER $\alpha-/-$ and ER $\alpha+/+$ female mice were castrated at 6-7 weeks of age by bilateral ovariectomy (OVX) under anesthesia (2.5\% Avertin). OVX mice were then implanted with subcutaneous hormone pellets (Innovative Research, Toledo, OH, USA) designed for slow release of $6 \mu \mathrm{g} /$ day of exogenous $E_{2}$ as $17 \beta$ estradiol (exogenous $\mathrm{E}_{2}-6 ; n=19$ and $n=18$ for $\mathrm{ER} \alpha-/-$ and $\mathrm{ER} \alpha+/+$ mice, respectively), or $8 \mu \mathrm{g} /$ day of exogenous $\mathrm{E}_{2}$ as $17 \beta$-estradiol (exogenous $\mathrm{E}_{2}-8 ; n=21$ and $n=20$ for ER $\alpha-/-$ and $E R \alpha+/+$ mice, respectively) for a total of up to 4 months. The 6- $\mu \mathrm{g} /$ day $E_{2}$ dose was chosen based on analogous models indicating that this dosage attains blood levels at peak estrus necessary to lower plasma lipids and plaque size [30-32]. The 8- $\mu \mathrm{g} /$ day $\mathrm{E}_{2}$ dose was chosen to assess the dose-response of exogenous $\mathrm{E}_{2}$ and the impact of higher $\mathrm{E}_{2}$ dose and levels on atheroprotection. OVX ER $\alpha-/-(n=22)$ and ER $\alpha+/+(n=20)$ mice implanted with placebo vehicle pellets served as $\mathrm{E}_{2}$-deficient controls. In addition, ER $\alpha-/-(n=18)$ and $\mathrm{ER} \alpha+/+(n=19)$ female mice with ovaries left intact served as an additional study group for evaluating the comparative vascular effect of endogenous $\mathrm{E}^{2}$. Intact $\mathrm{ER} \alpha$-deficient females have generally been excluded from prior studies due to plasma $\mathrm{E}_{2}$ levels that are higher than wild-type mice as a consequence of their estrogen insensitivity [37]. However, we chose to include these mice to evaluate the effect of higher endogenous estrogen in our model.

To induce atherosclerotic lesions, mice were fed a highfat, high-cholesterol, atherogenic diet [38, 39], herein referred to as the atherogenic diet (Purina; 15\% wt/wt butter fat, $1.25 \% \mathrm{wt} / \mathrm{wt}$ cholesterol, and $0.5 \%$ cholic acid) for 4 months starting 1 week after surgical recovery from OVX. The diet was formulated to be phytoestrogen-free. Aortas (five to eight from each genotype) were sampled for lesion formation at baseline (age 6-7 weeks, immediately before cholesterol feeding), and after 2 and 4 months on the atherogenic diet.

Aortic Atherosclerotic Lesion Analysis To determine extent of characteristics and extent of atherosclerotic lesions in aortas and determine any regional differences in atherosclerosis susceptibility, we adapted and optimized previously published and reproducible methods for atheroma quantification [40], as previously described [41]. Oil Red O-stained (Sigma) cryosections $(10 \mu \mathrm{m}$ thick) defined and characterized neutral lipid in the vessel wall, permitting histological assessment and quantitative evaluation of lesions in three artery segment locations (proximal segment $=$ proximal aortic arch; mid segment $=$ suprarenal aorta; distal segment=infrarenal aorta proximal to the iliac bifurcation). Fatty streaks (herein, early lesions) were analyzed for area, location, and quantity by direct imaging (Olympus BX-40 Microscope, Olympus DP11 Camera with $64 \mathrm{MB}$ smart media chip). Quantitative total lesion area and mean lesion size $\left(\mu \mathrm{m}^{2} \pm \mathrm{SEM}\right)$ for each early lesion was determined morphometrically (Image Pro Plus, version 4.1). Qualitative morphological assessment of lesion complexity used, as parameters, extent of subintimal lipid deposition and ORO staining and absence or presence of foam cells. Wall thickness, disruption of vessel wall architecture, and distortion of nuclear proliferation were not assessed as they were not part of the early-lesion pathology in the study's early-lesion model. For each mouse, a total of 36 cryosections (discarding every other section) were obtained from the proximal, mid, and distal aortic segments for extensive sampling of a total of $>2,100 \mu \mathrm{m}$ per aorta.

Measurement of Uterine Weight The entire uterus was collected at baseline and 2 and 4 months to assess in vivo exposure to estradiol. Serosal fat was removed, the uterus divided from the utero-tubal junction bilaterally, transected at the junction of the uterine body and cervix, and uterine wet weight recorded relative to body weight.

Quantification of Plasma Estradiol Plasma levels of free $17 \beta$-estradiol were determined in study mice at baseline and 2 and 4 months on the atherogenic diet. Assays were performed in duplicate by enzyme immunoassay (Cayman Chemical, Ann Arbor, MI, USA) on nonpooled plasma samples.

Quantification of Plasma Lipids Plasma lipid levels were measured in study mice at baseline and 2 and 4 months on 
the atherogenic diet and analyzed as follows: triglyceride (TG) with Triglyceride (INT) Reagent (Sigma); highdensity lipoprotein cholesterol (HDL-C) with a colorimetric reagent kit (Wako) after precipitating the ApoB-containing particles; and total cholesterol (TC) using a GM7 Analox Analyzer (Analox). All assays were performed in duplicate on nonpooled plasma samples.

Statistical Analysis Lesion area and lesion number were quantified by calculating the total lesion area and total number of lesions, respectively, in each of the 36 aortic sections for each mouse aorta. Comparisons between study groups were made using Student's $t$ test for independent samples (two-tailed), and analysis of variance, using MSOffice 2000 Excel software for PC and Sigma Stat version 2.03 (SPSS). Genotype (ER $\alpha-/-$ versus $\mathrm{ER} \alpha+/+)$ and $\mathrm{E}_{2}$ status (OVX, Intact, $\mathrm{E}_{2}-6$, and $\mathrm{E}_{2}-8$ ) were the grouping variables. Correlations between parameters were analyzed using simple linear regression. Probability values at $\alpha<0.05$ identified all statistically significant comparisons.

\section{Results}

Plasma Estradiol We determined plasma estradiol levels in study mice. We successfully achieved the desired hormonal status in all of the mice (Fig. 1a). OVX reduced circulating plasma $\mathrm{E}_{2}$ to very low levels in $\mathrm{ER} \alpha-/-$ and $\mathrm{ER} \alpha+/+$ mice. $\mathrm{E}_{2}$ levels in intact $\mathrm{ER} \alpha-/-$ mice were more than twice those of intact $\mathrm{ER} \alpha+/+$ mice $(p<0.05)$, consistent with the previously reported ER-dependent functional estrogen insensitivity of $E R \alpha-/-$ mice [42]. Plasma $E_{2}$ in exogenous $\mathrm{E}_{2}$-replaced $\mathrm{ER} \alpha-/-$ and $\mathrm{ER} \alpha+/+$ mice were at or above peak estrus levels, previously reported necessary for physiologic atheromatous plaque reduction [30-32]. With $\mathrm{E}_{2}$ replacement, female mice have been previously reported to develop carcinoma of the cervix and urinary tract and reproductive tract pathology [43]. None of our study mice developed cervical carcinoma with $\mathrm{E}_{2}$. However, three mice developed endometritis, hydronephrosis, and bladder enlargement unassociated with infection. These mice were excluded from subsequent analysis.

Uterine weights were measured to functionally assess in vivo $E_{2}$ action in our system (Fig. 1b). In ER $\alpha+/+$ mice, the very small, atrophic uteri of $\mathrm{E}_{2}$-deficient $\mathrm{OVX}$ female mice confirmed the absence of estrogenic stimulation. ER $\alpha+/+$ mice with endogenous $\mathrm{E}_{2}$ had significantly $(p<0.01)$ larger uteri than OVX females. Uterine weights of OVX ER $\alpha+/+$ female mice replaced with exogenous $E_{2}-6$ and $E_{2}-8$ were over 8-fold larger than OVX ER $\alpha+/+$ females $(p<0.05)$ and 4 -fold larger than intact $\mathrm{ER} \alpha+/+$ mice $(p<0.05)$. As expected, in ER $\alpha-1-$ mice, uteri were consistently small
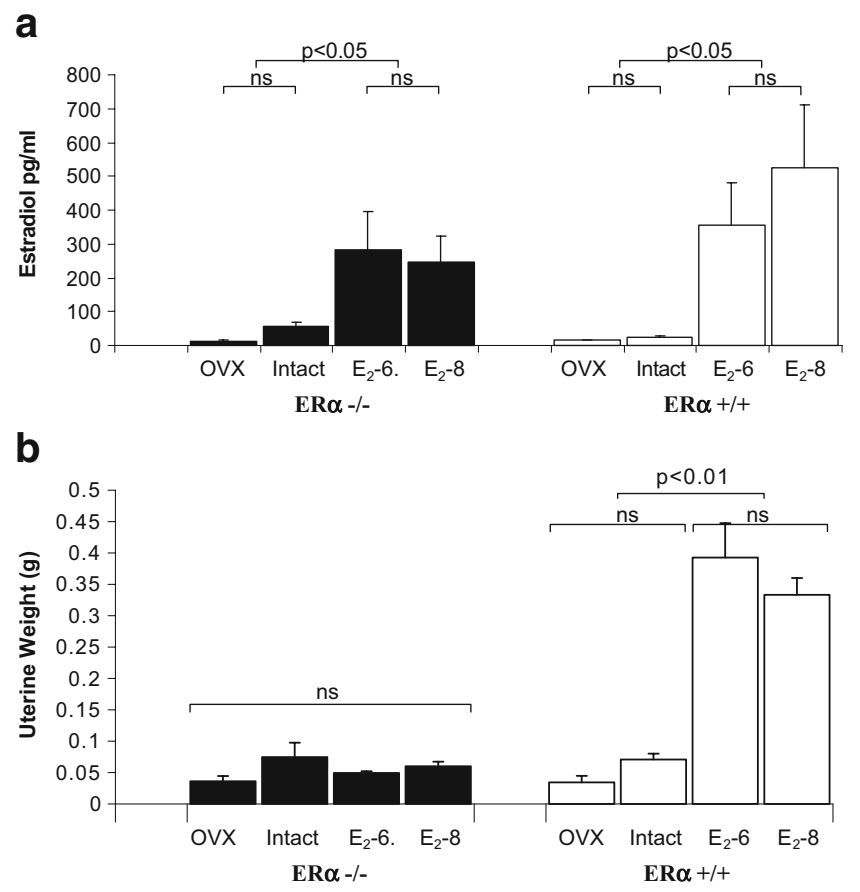

Fig. 1 a Plasma estradiol levels in ER $\alpha-/-$ and $E R \alpha+/+$ female mice. Levels of plasma $17 \beta$-estradiol (pg/ml; mean \pm SEM) in ER $\alpha-/-$ and $\mathrm{ER} \alpha+/+$ female study mice are shown for ovariectomized $(O V X, n=$ 14-15), intact $(n=6-10)$, and ovariectomized replaced with estradiol pellets designed to deliver $6 \mu \mathrm{g} /$ day $\left(E_{2}-6 ; n=10-12\right)$ and $8 \mu \mathrm{g} /$ day $\left(E_{2}-8 ; n=8-13\right)$. Statistically significant $(p<0.05)$ and non-significant (ns) comparisons are shown for each genotype. There were no significant differences for treatment group comparisons between genotypes. b Uterine weights in ER $\alpha-/-$ and $E R \alpha+/+$ female mice. Uterine weights $(\mathrm{g}$; mean $\pm \mathrm{SEM})$ in $\mathrm{ER} \alpha-/-$ and $\mathrm{ER} \alpha+/+$ female study mice are shown for ovariectomized (OVX, n=4-6), intact $(n=$ $5-7)$, and ovariectomized replaced with estradiol pellets designed to deliver $6 \mu \mathrm{g} /$ day $\left(E_{2}-6 ; n=13-14\right)$ and $8 \mu \mathrm{g} /$ day $\left(E_{2}-8 ; n=6-14\right)$. Statistically significant $(p<0.01)$ and non-significant $(\mathrm{ns})$ comparisons are shown for each genotype. In addition, there were significant differences $(p<0.01)$ for uterine weight comparisons between $\mathrm{ER} \alpha+/+$ $\mathrm{E}_{2}-6$ and $\mathrm{E}_{2}-8$ and all $\mathrm{ER} \alpha-/-$ treatment groups

and did not significantly enlarge with $\mathrm{E}_{2}$ treatment. Although $\mathrm{E}_{2}$ has reported effects on body weight in humans and several animal species [44, 45], there were no significant differences in body weight between ER $\alpha-/-$ and $\mathrm{ER} \alpha+/+$ mice in our different treatment groups and experimental time points (data not shown).

Plasma Lipids Figure 2 summarizes fasting plasma lipids for total cholesterol, triglycerides, and high-density lipoprotein cholesterol for OVX, intact, and $\mathrm{E}_{2}$-replaced $\mathrm{ER} \alpha-/-$ and $\mathrm{ER} \alpha+/+$ female mice while on the atherogenic diet. TC was lower at baseline in $\mathrm{ER} \alpha+/+$ mice than in $\mathrm{ER} \alpha-/-$ mice ( $73 \pm 11 \mathrm{mg} / \mathrm{dl}$ versus $104 \pm 5 \mathrm{mg} / \mathrm{dl}$, respectively, $p=\mathrm{ns}$ ). Compared to baseline, after 4 months on the atherogenic diet, fasting TC increased significantly $(p<0.05)$ in OVX, endogenous $\mathrm{E}_{2}$, and exogenous $\mathrm{E}_{2}-6 \mathrm{ER} \alpha-/-$ and $\mathrm{ER} \alpha+/+$ mice $(32 \%, 28 \%$, and $30 \%$ versus $55 \%, 58 \%$, and $55 \%$ for 


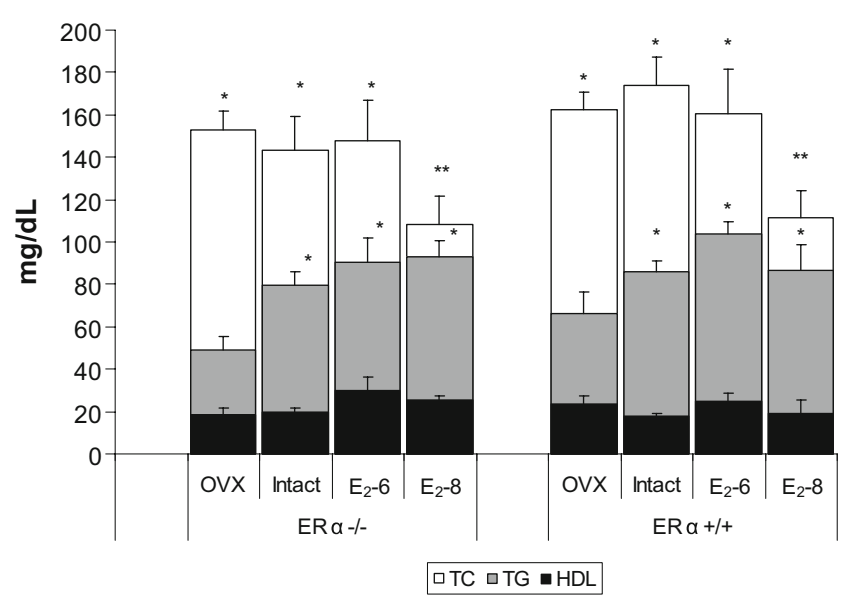

Fig. 2 Plasma lipid levels in ER $\alpha-/-$ and $E R \alpha+/+$ female mice. Fasting lipid levels $(\mathrm{mg} / \mathrm{dl}$; mean $\pm \mathrm{SEM})$ for total cholesterol $(T C)$, triglyceride $(T G)$, and high-density lipoprotein $(H D L)$ were determined in non-pooled plasma of ER $\alpha-/-(n=50$ samples for each lipid $)$ and ER $\alpha+/+(n=49$ samples for each lipid) female mice on the atherogenic diet for animals ovariectomized $(O V X)$, intact, and ovariectomized replaced with estradiol pellets designed to deliver $6 \mu \mathrm{g} /$ day $\left(E_{2}-6\right)$ and $8 \mu \mathrm{g} /$ day $\left(E_{2}-8\right) .{ }^{*} p<0.05$ versus lipid baseline values (not shown, see text) prior to cholesterol feeding for each genotype; ${ }^{*} p<0.05$ versus TC in other treatment groups for a given genotype

each genotype, respectively; $p=\mathrm{ns}$ for treatment group comparisons between genotypes). However, the atherogenic diet-associated increase in TC in ER $\alpha-/-$ and $\mathrm{ER} \alpha+/+$ mice was not affected by estrogen treatments in any of the study groups, except for a significant $(p<0.05)$ reduction in TC with exogenous $\mathrm{E}_{2}-8$ only observed in both $\mathrm{ER} \alpha-/-$ and $\mathrm{ER} \alpha+/+$ mice.

In addition, TC levels on the atherogenic diet in OVX and intact $\mathrm{ER} \alpha+/+$ mice did not correlate with lesion area and correlated poorly with lesion area in exogenous $E_{2}-6$ $\mathrm{ER} \alpha+/+$ mice $(r=0.56 ; p=\mathrm{ns})$. However, in $\mathrm{ER} \alpha+/+$ mice, the reduction in $\mathrm{TC}$ with exogenous $\mathrm{E}_{2}-8$ correlated strongly with reduction in fatty streak size $(r=0.83 ; p<0.05)$. In $\mathrm{ER} \alpha-/-$ mice, aortic lesion area did not correlate with TC in any of the treatment groups. Thus, with the sole exception of $\mathrm{E}_{2}-8$ in $\mathrm{ER} \alpha+/+$ mice, the dramatic reduction in lesion size with $E_{2}$ (endogenous or exogenous) in $\mathrm{ER} \alpha-/-$ and $\mathrm{ER} \alpha+/+$ mice was not a consequence of an estrogen-mediated reduction in TC levels.

There were no significant differences in baseline fasting plasma TG levels between ER $\alpha-/-$ and ER $\alpha+/+$ female mice $(75 \pm 6$ and $81 \pm 13 \mathrm{mg} / \mathrm{dl}$, respectively). While on the atherogenic diet, fasting levels of plasma TG increased significantly $(p<0.05)$ in all $\mathrm{E}_{2}$ mouse groups, compared to baseline or OVX (Fig. 2). However, increases in TG did not correlated with lesion formation in any of the treatment groups or genotypes.

Fasting levels of HDL-C were similar at baseline in $\mathrm{ER} \alpha-/-$ and $\mathrm{ER} \alpha+/+$ mice $(13 \pm 2$ and $17 \pm 4 \mathrm{mg} / \mathrm{dl}$, respectively). Compared to baseline, HDL levels tended to be significantly greater in hormone replaced $\mathrm{ER} \alpha-/-$ mice than $\mathrm{ER} \alpha+/+$ mice. However, there were no significant changes in HDL-C levels between treatment groups in $\mathrm{ER} \alpha+/+$ mice on the atherogenic diet (Fig. 2). Furthermore, there was no correlation between lesion area and HDL-C levels in either genotype.

Lesion Area, Number, and Distribution ER $\alpha-/-$ and $\mathrm{ER} \alpha+/+$ mice developed aortic lesions typical of fatty streaks [38]. The fatty-streak lesion area (averaged throughout the period on the atherogenic diet) for all treatment groups is summarized in Fig. 3. Endogenous and exogenous $E_{2}$ were both very effective in inhibiting early lesion formation. In both $\mathrm{ER} \alpha-/-$ and $\mathrm{ER} \alpha+/+$ female mice, endogenous $E_{2}$ in mice with intact ovarian function and exogenous $E_{2}$ in estrogen-replaced OVX mice significantly reduced lesion area compared with $\mathrm{E}_{2}$-deficient $\mathrm{OVX}$ mice. Compared to OVX, lesions in mice with endogenous $\mathrm{E}_{2}$ were $64 \%$ and $55 \%$ smaller in ER $\alpha-/-$ and $\mathrm{ER} \alpha+/+$ mice, respectively $(p<0.001)$. In addition, following exogenous $\mathrm{E}_{2}$ replacement, lesions were more than $90 \%$ smaller $(p<$ 0.001 ) in both $\mathrm{ER} \alpha-/-$ and $\mathrm{ER} \alpha+/+$ mice compared to OVX mice. No significant difference in lesions was observed between the two doses of exogenous estradiol $\left(\mathrm{E}_{2}-6\right.$ and $\left.\mathrm{E}_{2}-8\right)$ in $\mathrm{ER} \alpha-/-$ or $\mathrm{ER} \alpha+/+$ mice. In addition, the rate at which lesions developed over time appeared to

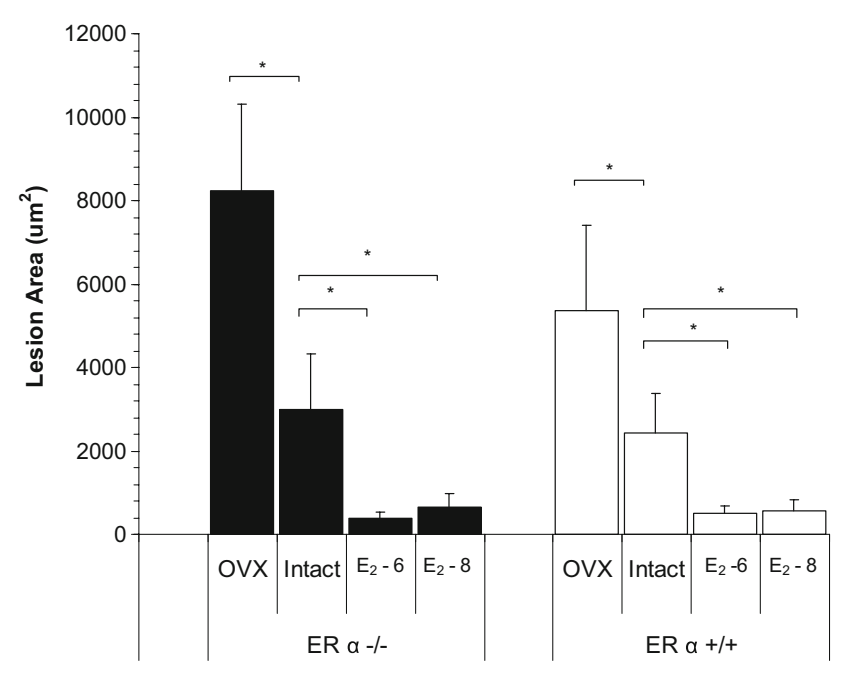

Fig. 3 Early lesion formation in ER $\alpha+/+$ and $E R \alpha-/-$ female mice. Lesion area $\left(\mu \mathrm{m}^{2} \pm \mathrm{SEM}\right)$ of early atherosclerotic fatty streaks in the aortas of ER $\alpha-/-(n=80)$ and ER $\alpha+/+$ female mice $(n=77)$ was measured at baseline and 2 and 4 months of cholesterol feeding ( $n=$ 5-7 mice each per genotype, treatment group, and time point). Lesion area is shown for mice ovariectomized $(O V X)$, intact, and ovariectomized replaced with estradiol pellets designed to deliver $6 \mu \mathrm{g} /$ day $\left(E_{2}-\sigma\right)$ and $8 \mu \mathrm{g} /$ day $\left(E_{2}-8\right)$. Data are mean \pm SEM lesion area $\left(\right.$ in $\left.\mu \mathrm{m}^{2}\right)$. ${ }^{*} p<0.001$ compared to the indicated treatment groups for a given genotype 
decline with increasing estrogenic action in both ER $\alpha-/-$ and $\mathrm{ER} \alpha+/+$ mice but did not differ between the two genotypes (data not shown).

For each of the $E_{2}$ treatment groups, representative histological lesions of female ER $\alpha-/-$ and $\mathrm{ER} \alpha+/+$ mice after 4 months on the atherogenic diet are shown (Fig. 4). Early atherosclerotic lesions were present in the intimal layer of aortas of both ER $\alpha-/-$ and ER $\alpha+/+$ mice as early as 2 months on the atherogenic diet, with more extensive lesions developing over the 4 months of the study. Lesions were distinguished by lipid infiltration into the vessel wall and the presence of fatty streaks and did not have characteristics of advanced lesions, confirming our model of early atherosclerosis. Compared to endogenous and exogenous $\mathrm{E}_{2}$, OVX ER $\alpha-/-$ and $\mathrm{ER} \alpha+/+$ mice had early lesions that were more extensive and lipid rich and with larger deposits of intra- and extra-cellular lipid. Lesions in $\mathrm{ER} \alpha-/-$ and $\mathrm{ER} \alpha+/+$ endogenous $\mathrm{E}_{2}$ mice had less lipid deposits than OVX mice but more fatty streaking of the sub-endothelium than exogenous $E_{2}$ mice. Lesion formation was essentially absent in mice replaced with exogenous $E_{2}$.

We also characterized early lesions by quantity and segment location in the aorta. The segmental distribution of early lesions in aortas of ER $\alpha-/-(n=51,48,54$, and 54 total segments for OVX, intact, $\mathrm{E}_{2}-6$, and $\mathrm{E}_{2}-8$, respectively) and $\mathrm{ER} \alpha+/+$ mice $(n=51,51,51$, and 54 total segments for OVX, intact, $E_{2}-6$, and $E_{2}-8$, respectively) is shown in Fig. 5. All mice showed predilection for early lesion formation in the proximal aortic segment, with $83-100 \%$ of all early lesions localized to this region of the aorta. The mid aorta contained $2-18 \%$ of early lesions, whereas $<3 \%$ of early lesions were in the distal aorta. Differences in distribution of lesions were significant $(p<0.01)$ between segments (proximal versus mid versus distal aorta), and compared to endogenous or exogenous $\mathrm{E}_{2}$, there was significantly greater ( $\sim 4$-fold) proximal distribution of lesions in OVX mice. However, lesion distribution was not significantly affected by ER $\alpha$ status.

The number of lesions in aortas of exogenous $\left(\mathrm{E}_{2}-6\right.$ and $\left.\mathrm{E}_{2}-8\right) \mathrm{ER} \alpha-/-$ mice was significantly lower $(p<0.05)$ than

Fig. 4 Representative cross sections of lesions from the aortas of ER $\alpha-/-$ And ER $\alpha+/+$ mice. Histochemistry of examples of representative cross sections $(10 \mu \mathrm{m})$ of lesions from the proximal aorta of cholesterol fed (4 months) ER $\alpha-/-$ (right panel) and ER $\alpha+/+$ (left panel) female mice for the following experimental groups: ovariectomized $(O V X)$, ovaries intact, and ovariectomized replaced with estradiol pellets designed to deliver $6 \mu \mathrm{g} /$ day $\left(E_{2}-\sigma\right)$ and $8 \mu \mathrm{g} /$ day $\left(E_{2}-8\right)$. The vessels have been stained for lipid with Oil-red-O and counterstained with Gill's Hematoxylin. A normal vessel prior to the initiation of cholesterol feeding, baseline, is shown for comparison. The representative images $(\times 20$ magnification) demonstrate redstaining subintimal lipid deposits and fatty streaks. Cross sections are oriented with the lumen to the right and the adventitial surface to the left of each image. Size markers $=20 \mu \mathrm{m}$ in aortas of OVX ER $\alpha-/-$ mice. In ER $\alpha-/-$ mice, the mean number of lesions in endogenous $E_{2}, E_{2}-6$, and $E_{2}-8$ mice was $12 \pm 5,8 \pm 2$, and $10 \pm 2$, respectively, compared to a mean of $41 \pm 7$ lesions in the aortas of OVX mice $(p<0.05)$. In $\mathrm{ER} \alpha+/+$ mice, a similar pattern was observed with

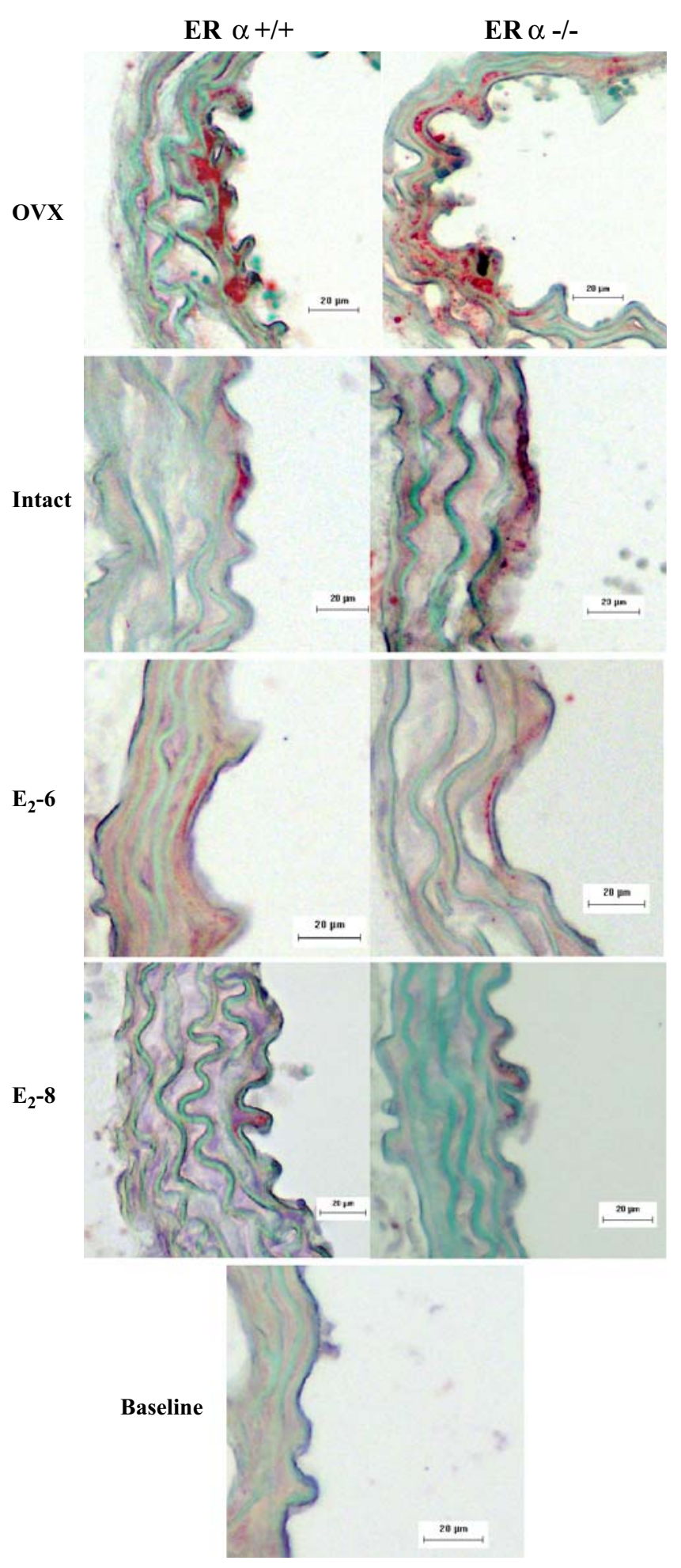




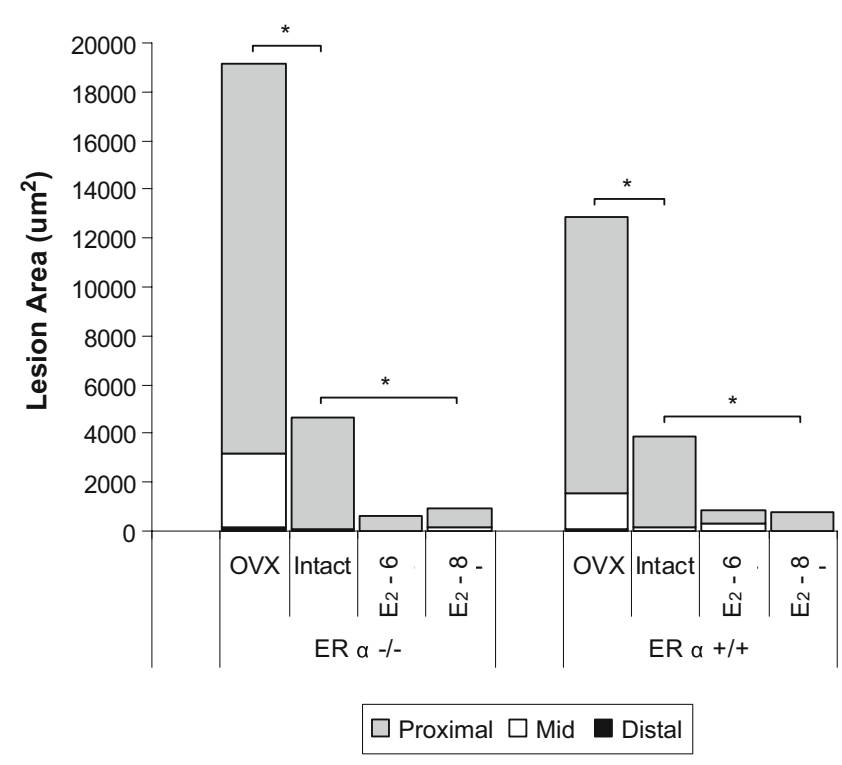

Fig. 5 Lesion distribution in aortic segments of ER $\alpha-/-$ and $E R \alpha+/+$ female mice. Lesion area $(\mu \mathrm{m} 2$; mean \pm SEM) was determined in the proximal, mid, and distal aortic segments of female ER $\alpha-/-$ and ER $\alpha+/+$ mice ovariectomized (OVX, $n=29)$, intact $(n=23)$, and ovariectomized replaced with estradiol pellets designed to deliver $6 \mu \mathrm{g} /$ day $\left(E_{2}-6 ; n=25\right)$ and $8 \mu \mathrm{g} /$ day $\left(E_{2}-8 ; n=24\right)$. See text for details. ${ }^{*} p<0.01$ versus other treatment groups of the same genotype

exogenous $\mathrm{E}_{2}$ mice having fewer lesion than OVX or intact mice.

Relationship of Plasma Estradiol and Lesions In our system, early lesion formation was inversely correlated with plasma estradiol levels in both ER $\alpha-/-$ and $E R \alpha+/+$ mice. This relationship is demonstrated in Fig. 6. A stepwise reduction in lesion size was observed with a rise in plasma estradiol, and a converse step-wise increase in lesion size was seen with a drop in plasma estradiol. OVX animals had a mean plasma estradiol of only $13 \mathrm{pg} / \mathrm{ml}$ (we assume that the residual measurable estradiol in OVX mice is due to adrenal sex steroid production and conversion to estradiol) and the greatest extent of lesions. Intact mice with endogenous $\mathrm{E}_{2}$, in which mean plasma estradiol levels were $58 \mathrm{pg} / \mathrm{ml}$, demonstrated nearly $60 \%$ reduction in lesion size $(p<0.05)$. As expected, intact $\mathrm{ER} \alpha-/-$ females had relatively greater endogenous $\mathrm{E}_{2}$ levels than intact $\mathrm{ER} \alpha+/+$ mice due to their relative insensitivity to estrogen. However, the differences in endogenous $\mathrm{E}_{2}$ levels between these mice were relatively small and not sufficient to result in significant differences in aortic lesions in our studies. However, with higher plasma estradiol levels (mean $>247 \mathrm{pg} / \mathrm{ml}$ attained in exogenous $E_{2}$ mice), lesion development was essentially eliminated compared to endogenous $\mathrm{E}_{2}$ and OVX mice $(<0.05)$. The inverse relationship between mean serum estradiol and mean lesion area was unaffected by $\mathrm{ER} \alpha$ status as it did not significantly differ between the two $\mathrm{ER} \alpha$ genotypes.

\section{Discussion}

The important new finding of our studies is that protection from development of early atherosclerotic lesions (fatty streaks) is dependent on estrogen but independent of the $\mathrm{ER} \alpha$. In addition, estrogen atheroprotection was estrogenlevel dependent, with greater atheroprotection offered by exogenous estrogen compared to endogenous estrogen and loss of atheroprotection with ovariectomy.

Atheroprotection by $\mathrm{E}_{2}$ in atherogenic transgenic mouse models with targeted inactivation of the low-density lipoprotein receptor [32] and apolipoprotein $\mathrm{E}$ [30, 31] has been demonstrated. In these models, mice spontaneously develop advanced atherosclerosis. In a combined ApoE/ER $\alpha$ deletion model [33], ER $\alpha$ was reported to be a major mediator of $E_{2}$ protection in advanced atherosclerotic lesions. However, whether the same occurs in early-stage lesions is unknown. In this paper, we demonstrate several novel findings: (1) $E_{2}$ inhibits and delays the development of early lesions by ER $\alpha$-independent mechanisms, as there was no significant interaction between ER $\alpha$ genotype and hormone treatment or hormone status. (2) There was an estrogen concentration-dependent response to atheroprotection. And (3) Endogenous and exogenous $E_{2}$ are both highly, though not equally, effective in attenuating aortic lesion development and progression. In our model, inhibition of early lesions using exogenous $\mathrm{E}_{2}$ in ovariectomized

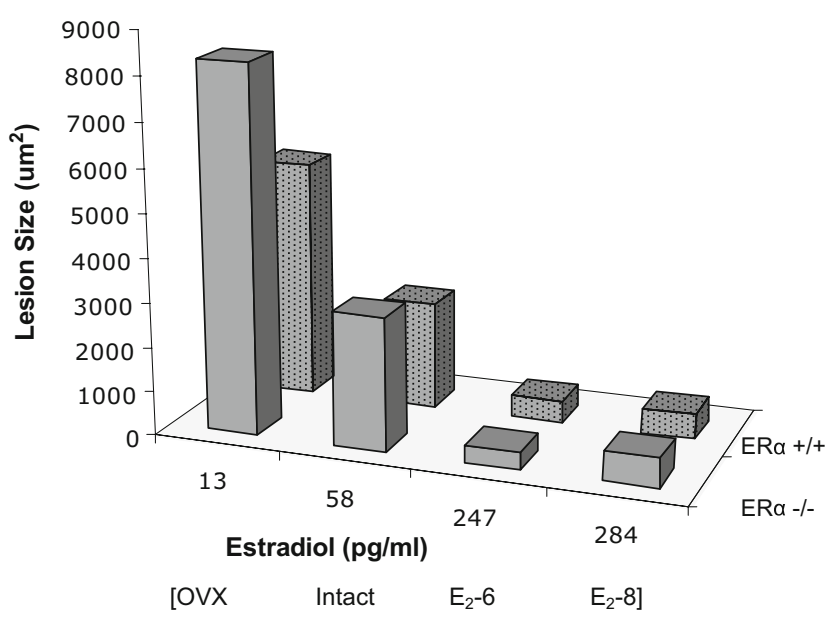

Fig. 6 Reduction in lesion area as a function of plasma estradiol. Lesion area $\left(\mu \mathrm{m}^{2} \pm \mathrm{SEM}\right)$ as a function of plasma $17 \beta$-estradiol $\left(\mathrm{E}_{2}\right.$; $\mathrm{pg} / \mathrm{ml}$; mean) in $\mathrm{ER} \alpha-/-$ and $\mathrm{ER} \alpha+/+$ female study mice. Estradiol values (mean, $\mathrm{pg} / \mathrm{ml}$ ) are indicated for mice ovariectomized, OVX $\left(E_{2}=13 \mathrm{pg} / \mathrm{ml}\right)$, intact $\left(E_{2}=58 \mathrm{pg} / \mathrm{ml}\right)$, and ovariectomized and replaced with $E_{2}$ pellets designed to deliver $6 \mu \mathrm{g} /$ day $\left(E_{2}-6=\right.$ $247 \mathrm{pg} / \mathrm{ml})$ and $8 \mu \mathrm{g} /$ day $\left(\mathrm{E}_{2}-8=284 \mathrm{pg} / \mathrm{ml}\right)$ 
animals was more atheroprotective than leaving the ovaries (and thus endogenous $E_{2}$ levels) untouched. This was somewhat surprising since the dosage used was chosen to obtain blood $\mathrm{E}_{2}$ levels similar to those at peak estrous, though actual serum $E_{2}$ levels attained were at times higher. However, we do not think that this is the reason that inhibition of early lesions using exogenous $E_{2}$ therapy in ovariectomized animals was more effective at inhibiting early lesion formation than endogenous $\mathrm{E}_{2}$. A more likely possibility to consider is that cycling estrogen levels may attenuate the growth inhibitory effect of endogenous $E_{2}$, in contrast to continuous therapy in our model.

Our findings also extend recent observations reported in ApoE $\mathrm{KO}$ mice in which $\mathrm{E}_{2}$ treatment failed to reduce aortic lesions in ApoE-deficient mice also lacking $\mathrm{ER} \alpha$ [33]. We postulate that the differences between our findings and previous are due to two principal factors: (a) the difference in the animal model used and (b) the differences in estradiol effect in early- versus late-stage atherosclerosis. In the previous report, the experimental strain used was the heterozygous $\mathrm{ER} \alpha$ deletion on the atherogenic ApoE null transgenic mouse background. In contrast, the current study used ER $\alpha$-Neo null mice on a mixed $129 / \mathrm{J}$ and $\mathrm{C} 57 \mathrm{Bl} / 6 \mathrm{~J}$ background. Such mixed background mice are relatively protected from atherosclerosis and thus, a cholesterolcontaining diet was used to induce aortic fatty streaks that did not progress to more mature atheroma. We took advantage of this model to specifically study $E_{2}$ and $E R \alpha$ effects on early-stage disease. Secondly, the current study examined the early stages of atherosclerosis, whereas the previous report examined more advanced lesions of atherosclerosis. The differential effects of $E_{2}$ treatment on early-stage atherosclerosis as opposed to the more advanced stages and how ER $\alpha$ is associated with one but not the other are very important observations and distinctions with keen relevance to better understanding atherosclerotic cardiovascular disease. Sex steroid hormones are critical determinants of cardiovascular sex differences. Moreover, the effects of estrogens on the blood vessel wall depend upon the extent and complexity of atherosclerotic disease present at the time hormone therapy is initiated. As atherosclerosis evolves, the early vascular protective mechanisms of estrogen (e.g., increased NO and cyclooxygense 2 and decreased TNF- $\alpha$, cell adhesion molecules, LDL oxidation/binding, platelet activation, and vascular smooth muscle cell proliferation) recede and are replaced by estrogen responses that may be deleterious (decrease in ER function/expression and vasodilation and increase in inflammatory activation and plaque instability). These events have recently been comprehensively reviewed by Turgeon et al. [46], Clarkson [47], and Manson [48]. Thus, it is becoming increasingly clear that the pleiotropic effects of hormone therapy on the vascular system and cells differ, depending not only on hormone status, but also importantly on the stage of atherosclerosis in the underlying blood vessel.

We also examined whether the atheroprotective effects of $E_{2}$ on early atherosclerosis were lipid mediated. However, the extent of atheroprotection attributable to $E_{2}$ in our study and previous studies [30-33] is clearly greater than can be accounted for by changes in lipid parameters alone. In LDL-R-/- mice [32], exogenous $E_{2}$, but not endogenous $\mathrm{E}_{2}$, lowers cholesterol. In the $\mathrm{ER} \alpha-/-$ and $\mathrm{ER} \alpha+/+$ mice, lipid levels at baseline and following an atherogenic diet were similar to those previously published for atherosclerosis-susceptible mouse strains [38] and concur with those reported in ApoE-deficient mice, where only high doses of exogenous $\mathrm{E}_{2}$ reduced plasma cholesterol [30]. However, the protective effects of endogenous and exogenous $E_{2}$ against fatty-streak formation in our studies were not correlated with plasma levels of TC, TG, or HDL-C. Thus, in our model, the traditional factors that promote lesion formation, such as a high-fat diet and high plasma cholesterol, did not interact with $\mathrm{ER} \alpha$ genotype as the changes in serum lipoproteins were independent of $\mathrm{ER} \alpha$ expression and occurred in both $\mathrm{ER} \alpha-/-$ and $+/+$ female mice.

Our studies had some limitations. The ER $\alpha$-deficient mouse used (ER $\alpha$-Neo KO) is not fully null $[35,49,50]$. In this mouse, the ER $\alpha$ gene was disrupted by the insertion of the neomycin gene into the first coding exon, resulting in deficiency of the full-length wild-type ER $\alpha$ protein [34]. This approach also results in the expression of two alternatively spliced transcripts of the disrupted ER $\alpha$ gene, E1 and E2 [35], and the expression of two variant ER $\alpha$ proteins (only one of them found in the aorta) [35, 49]. This alternative $\mathrm{ER} \alpha$ protein has residual low-level, highaffinity, estradiol-binding activity $[35,36]$ but lacks the specificity to be from either ER $\alpha$ or ER $\beta$ (Liu and Lubahn, unpublished data). This variant also has some estrogendependent transcriptional activity [35, 49, 50]-ER $\alpha$ transcriptional activity is mediated through two activation functions, AF1 and AF2, whose activity is tightly regulated in a cell-specific manner through yet unknown processes. More recently, mice completely deficient of the ER $\alpha$ gene by excision of exon $2(\mathrm{ER} \alpha-\Delta 2 \mathrm{KO})$ [51] resulted in the complete abrogation of an estradiol effect [49]. Although our studies used the ER $\alpha$ Neo KO model, the results presented clearly indicate that any residual activity of the variant of $\mathrm{ER} \alpha$ present in the aorta of this mouse model is not sufficient to protect against atherosclerosis in female mice, indicating that the expression of the full-length ER $\alpha$ is not required and that $\mathrm{ER} \alpha$ transcriptional activity mediated through the AF transactivation function is dispensable in protection against fatty-streak formation in the vessel wall. 
Although our findings indicate that $\mathrm{E}_{2}$ protects against the development of atherosclerosis by an ER $\alpha$ - and lipidindependent mechanism, we cannot conclude that the early atheroprotective effects of $\mathrm{E}_{2}$ occurred entirely via nonreceptor-mediated pathways. In $\mathrm{C} 57 \mathrm{BL} / 6 \mathrm{~J}$ mice, $\mathrm{E}_{2}$ prevents the vascular injury response to carotid artery denudation independent of ER $\alpha$ [52], perhaps proceeding via the ER $\beta$ [53]. Although the response to vascular injury differs from that of the atherosclerotic response to high fat feeding, a mechanistic role for ER $\beta$ seems unlikely in our system as the ER $\beta$ does not appear to be involved in early stages of atherosclerosis development [6]. Estrogen receptor ER $\beta$ localized to the vascular intima is correlated with coronary calcification and thus more advanced atherosclerosis in pre- and postmenopausal women [54], suggesting a role for this ER subtype in more advanced vascular disease. Recently, however, heat shock protein (HSP) 27, an ER $\beta$ associated protein, was demonstrated to have attenuated expression in coronary atherosclerosis and to modulate estrogen signaling in minimally diseased arteries [55]. Thus, in our system, vascular protective effects mediated by ER $\beta$ receptor, its isoforms [56], an as yet uncharacterized ER, HSPs, or other factors cannot be excluded and remain the work for future studies. Lastly, ER $\alpha$ - or ER $\beta$ independent effects of $E_{2}$ have been demonstrated for catechol estrogens (estrogens converted to catechol estrogens via oxidation) where inhibition of cell growth by $E_{2}$ is independent from ERs [57].

Furthermore, in clinical studies, the common estrogen receptor-alpha (ER-alpha) IVS1-401 C/C genotype polymorphism identifies a group of women (approximately $20 \%$ ) who have augmented response to hormone therapy. This has been demonstrated on levels of HDL cholesterol and intermediate cardiovascular risk markers, such as Eselectin $[58,59]$. Although the impact of this polymorphism on $\mathrm{ER} \alpha$ transcription and other estrogen-sensitive intermediate and clinical end points has not yet been established, the augmented effects of ER polymorphisms on hormone therapy regulation of lipids and other vascular mediators may be additional possible mechanisms by which ER polymorphisms might influence estrogen action in early atheroprotection. Thus, the implications of differing experimental results in various genetic models as extrapolations to human disease suggests that a polygenomic approach will be needed to fully understand whether exogenous estrogen treatments will be appropriate for all women and the timing of this treatment in relationship to atherosclerosis development.

In summary, this study addresses the atheroprotective role of estradiol that is uncoupled to that of the ER $\alpha$ and whether the mechanism of action of estradiol in atheroprotection is ER $\alpha$ dependent, or not, in early-stage lesions. Our findings demonstrate that, in early lesions of atherosclero- sis, the mechanism of atheroprotection is estradiol-mediated and not dependent on the extent of hyperlipidemia, a reduction in serum lipids by estrogen, or on the presence or absence of the ER $\alpha$. Our findings are important and provide new clues to the stage of vascular atherosclerosis at which estradiol and ER $\alpha$ protection occurs. Specifically, our observations establish that both endogenous and exogenous $E_{2}$ retard the development of fatty-streak formation characteristic of early atherosclerosis in a manner that is closely tied to estrogen level, yet independent of a functional $\mathrm{ER} \alpha$. In contrast, and based on prior studies, the $E R \alpha$ is required for a major part, if not all, of the $E_{2}-$ mediated reduction in lesion size in plaques with more advanced lesion characteristics and is a major mediator in plaque maturation. Furthermore, the inhibitory effects of $E_{2}$ on atherogenesis appear to be lost once atherosclerotic lesions are established [60].

In conclusion, our studies contribute to a better understanding of ER $\alpha$-dependent and -independent mechanisms of $E_{2}$ atheroprotection, linked to an emerging concept coupling estrogen action to the timing of its initiation in relationship to critical periods in the stages of atherogenesis. This knowledge is potentially very important, as one of the most critical areas of new focus in this field is understanding the molecular and phenotypic interface of estrogens with their receptors in the vascular wall vis-à-vis the stage(s) of atherosclerosis. A better understanding of this system may lead to a better understanding of how to optimize and when to target hormone therapies for cardiovascular disease protection in women.

Acknowledgments The authors wish to acknowledge personnel at the Murine Targeted Genomics Laboratory of the University of California, Davis Mouse Biology Program for technical assistance with rederivation and breeding of mice and Luis Zuniga for assistance with statistical analysis of the data. This work was supported by NIH K01-HL04142 to AV, The Frances Lazda Endowed Chair in Women's Cardiovascular Medicine, and The Nora Eccles Treadwell Foundation awards to AV, and NIH HL55667 award to JR.

Open Access This article is distributed under the terms of the Creative Commons Attribution Noncommercial License which permits any noncommercial use, distribution, and reproduction in any medium, provided the original author(s) and source are credited.

\section{References}

1. Mendelsohn, M. E., \& Karas, R. H. (1999). The protective effects of estrogen on the cardiovascular system. New England Journal of Medicine, 340, 1801-1811.

2. Stamler, J., Pick, R., \& Katz, L. N. (1953). Prevention of coronary atherosclerosis by estrogen-androgen administration in the cholesterol-fed chick. Circulation Research, 1, 94-98.

3. Adams, M. R., Kaplan, J. R., Manuck, S. B., Koritnik, D. R., Parks, J. S., Wolfe, M. S., et al. (1990). Inhibition of coronary artery atherosclerosis by 17 -beta estradiol in ovariectomized 
monkeys. Lack of an effect of added progesterone. Arteriosclerosis, 10, 1051-1057.

4. Chen, S. J., Li, H., Durand, J., Oparil, S., \& Chen, Y. F. (1996). Estrogen reduces myointimal proliferation after balloon injury of rat carotid artery. Circulation, 93, 577-584.

5. Oparil, S., Levine, R. L., Chen, S. J., Durand, J., \& Chen, Y. F. (1997). Sexually dimorphic response of the balloon-injured rat carotid artery to hormone treatment. Circulation, 95, 1301-1307.

6. Hodgin, J. B., \& Maeda, N. (2002). Minireview: estrogen and mouse models of atherosclerosis. Endocrinology, 143, 44954501.

7. Stampfer, M. J., Colditz, G. A., Willett, W. C., Manson, J. E., Rosner, B., Speizer, F. E., et al. (1991). Postmenopausal estrogen therapy and cardiovascular disease. Ten-year follow-up from the nurses' health study. New England Journal of Medicine, 325, 756-762.

8. Nabulsi, A. A., Folsom, A. R., White, A., Patsch, W., Heiss, G., $\mathrm{Wu}, \mathrm{K} . \mathrm{K}$., et al. (1993). Association of hormone-replacement therapy with various cardiovascular risk factors in postmenopausal women. The Atherosclerosis Risk in Communities Study Investigators. New England Journal of Medicine, 328, 10691075.

9. Hong, M. K., Romm, P. A., Reagan, K., Green, C. E., \& Rackley, C. E. (1992). Effects of estrogen replacement therapy on serum lipid values and angiographically defined coronary artery disease in postmenopausal women. American Journal of Cardiology, 69, $176-178$.

10. Rifici, V. A., \& Khachadurian, A. K. (1992). The inhibition of low-density lipoprotein oxidation by 17 -beta estradiol. Metabolism, 41, 1110-1114.

11. Sack, M. N., Rader, D. J., \& Cannon, R. O., 3rd. (1994). Oestrogen and inhibition of oxidation of low-density lipoproteins in postmenopausal women. Lancet, 343, 269-270.

12. Fogelberg, M., Vesterqvist, O., Diczfalusy, U., \& Henriksson, P. (1990). Experimental atherosclerosis: effects of oestrogen and atherosclerosis on thromboxane and prostacyclin formation. European Journal of Clinical Investigation, 20, 105-110.

13. Mikkola, T., Turunen, P., Avela, K., Orpana, A., Viinikka, L., \& Ylikorkala, O. (1995). 17 beta-estradiol stimulates prostacyclin, but not endothelin-1, production in human vascular endothelial cells. Journal of Clinical Endocrinology and Metabolism, 80, 1832-1836.

14. Weiner, C. P., Lizasoain, I., Baylis, S. A., Knowles, R. G., Charles, I. G., \& Moncada, S. (1994). Induction of calciumdependent nitric oxide synthases by sex hormones. Proceedings of the National Academy of Sciences of the United States of America, 91, 5212-5216.

15. Rossouw, J. E., Anderson, G. L., Prentice, R. L., LaCroix, A. Z., Kooperberg, C., Stefanick, M. L., et al. (2002). Risks and benefits of estrogen plus progestin in healthy postmenopausal women: principal results From the Women's Health Initiative randomized controlled trial. JAMA, 288, 321-333.

16. Anderson, G. L., Limacher, M., Assaf, A. R., Bassford, T., Beresford, S. A., Black, H., et al. (2004). Effects of conjugated equine estrogen in postmenopausal women with hysterectomy: the Women's Health Initiative randomized controlled trial. JAMA, 291, 1701-1712.

17. Hulley, S., Grady, D., Bush, T., Furberg, C., Herrington, D., Riggs, B., et al. (1998). Randomized trial of estrogen plus progestin for secondary prevention of coronary heart disease in postmenopausal women. Heart and Estrogen/progestin Replacement Study (HERS) Research Group. JAMA, 280, 605-613.

18. Grodstein, F., Manson, J. E., \& Stampfer, M. J. (2006). Hormone therapy and coronary heart disease: the role of time since menopause and age at hormone initiation. Journal of Womens Health (Larchmt), 15, 35-44.
19. Nadal, A., Diaz, M., \& Valverde, M. A. (2001). The estrogen trinity: membrane, cytosolic, and nuclear effects. News in Physiological Sciences, 16, 251-255.

20. Walter, P., Green, S., Greene, G., Krust, A., Bornert, J. M., Jeltsch, J. M., et al. (1985). Cloning of the human estrogen receptor cDNA. Proceedings of the National Academy of Sciences of the United States of America, 82, 7889-7893.

21. Kuiper, G. G., Enmark, E., Pelto-Huikko, M., Nilsson, S., \& Gustafsson, J. A. (1996). Cloning of a novel receptor expressed in rat prostate and ovary. Proceedings of the National Academy of Sciences of the United States of America, 93, 5925-5930.

22. Kuiper, G. G., Carlsson, B., Grandien, K., Enmark, E., Haggblad, J., Nilsson, S., et al. (1997). Comparison of the ligand binding specificity and transcript tissue distribution of estrogen receptors alpha and beta. Endocrinology, 138, 863-870.

23. Paech, K., Webb, P., Kuiper, G. G., Nilsson, S., Gustafsson, J., Kushner, P. J., et al. (1997). Differential ligand activation of estrogen receptors ERalpha and ERbeta at AP1 sites. Science, 277, 1508-1510.

24. Lindner, V., Kim, S. K., Karas, R. H., Kuiper, G. G., Gustafsson, J. A., \& Mendelsohn, M. E. (1998). Increased expression of estrogen receptor-beta mRNA in male blood vessels after vascular injury. Circulation Research, 83, 224-229.

25. Karas, R. H., Patterson, B. L., \& Mendelsohn, M. E. (1994). Human vascular smooth muscle cells contain functional estrogen receptor. Circulation, 89, 1943-1950.

26. Register, T. C., \& Adams, M. R. (1998). Coronary artery and cultured aortic smooth muscle cells express mRNA for both the classical estrogen receptor and the newly described estrogen receptor beta. Journal of Steroid Biochemistry and Molecular Biology, 64, 187-191.

27. Gulshan, S., McCruden, A. B., \& Stimson, W. H. (1990). Oestrogen receptors in macrophages. Scandinavian Journal of Immunology, 31, 691-697.

28. Losordo, D. W., Kearney, M., Kim, E. A., Jekanowski, J., \& Isner, J. M. (1994). Variable expression of the estrogen receptor in normal and atherosclerotic coronary arteries of premenopausal women. Circulation, 89, 1501-1510.

29. Bakir, S., Mori, T., Durand, J., Chen, Y. F., Thompson, J. A., \& Oparil, S. (2000). Estrogen-induced vasoprotection is estrogen receptor dependent: evidence from the balloon-injured rat carotid artery model. Circulation, 101, 2342-2344.

30. Bourassa, P. A., Milos, P. M., Gaynor, B. J., Breslow, J. L., \& Aiello, R. J. (1996). Estrogen reduces atherosclerotic lesion development in apolipoprotein E-deficient mice. Proceedings of the National Academy of Sciences of the United States of America, 93, 10022-10027.

31. Elhage, R., Arnal, J. F., Pieraggi, M. T., Duverger, N., Fievet, C., Faye, J. C., et al. (1997). 17 beta-estradiol prevents fatty streak formation in apolipoprotein E-deficient mice. Arteriosclerosis, Thrombosis, and Vascular Biology, 17, 2679-2684.

32. Marsh, M. M., Walker, V. R., Curtiss, L. K., \& Banka, C. L. (1999). Protection against atherosclerosis by estrogen is independent of plasma cholesterol levels in LDL receptor-deficient mice. Journal of Lipid Research, 40, 893-900.

33. Hodgin, J. B., Krege, J. H., Reddick, R. L., Korach, K. S., Smithies, O., \& Maeda, N. (2001). Estrogen receptor alpha is a major mediator of 17beta-estradiol's atheroprotective effects on lesion size in Apoe-/- mice. Journal of Clinical Investigation, 107, 333-340.

34. Lubahn, D. B., Moyer, J. S., Golding, T. S., Couse, J. F., Korach, K. S., \& Smithies, O. (1993). Alteration of reproductive function but not prenatal sexual development after insertional disruption of the mouse estrogen receptor gene. Proceedings of the National Academy of Sciences of the United States of America, 90, 1116211166. 
35. Couse, J. F., Curtis, S. W., Washburn, T. F., Lindzey, J., Golding, T. S., Lubahn, D. B., et al. (1995). Analysis of transcription and estrogen insensitivity in the female mouse after targeted disruption of the estrogen receptor gene. Molecular Endocrinology, 9, 1441-1454.

36. Kudwa, A. E., \& Rissman, E. F. (2003). Double oestrogen receptor alpha and beta knockout mice reveal differences in neural oestrogen-mediated progestin receptor induction and female sexual behaviour. Journal of Neuroendocrinology, 15, 978-983.

37. Couse, J. F., Lindzey, J., Grandien, K., Gustafsson, J. A., \& Korach, K. S. (1997). Tissue distribution and quantitative analysis of estrogen receptor-alpha (ERalpha) and estrogen receptor-beta (ERbeta) messenger ribonucleic acid in the wild-type and ERalpha-knockout mouse. Endocrinology, 138, 4613-4621.

38. Paigen, B., Morrow, A., Brandon, C., Mitchell, D., \& Holmes, P. (1985). Variation in susceptibility to atherosclerosis among inbred strains of mice. Atherosclerosis, 57, 65-73.

39. Wang, D. Q., Lammert, F., Cohen, D. E., Paigen, B., \& Carey, M. C. (1999). Cholic acid aids absorption, biliary secretion, and phase transitions of cholesterol in murine cholelithogenesis. American Journal of Physiology, 276, G751-760.

40. Paigen, B., Morrow, A., Holmes, P. A., Mitchell, D., \& Williams, R. A. (1987). Quantitative assessment of atherosclerotic lesions in mice. Atherosclerosis, 68, 231-240.

41. Villablanca, A., Lubahn, D., Shelby, L., Lloyd, K., \& Barthold, S. (2004). Susceptibility to early atherosclerosis in male mice is mediated by estrogen receptor alpha. Arteriosclerosis, Thrombosis, and Vascular Biology, 24, 1055-1061.

42. Couse, J. F., \& Korach, K. S. (1999). Estrogen receptor null mice: what have we learned and where will they lead us? Endocrine Reviews, 20, 358-417.

43. Cline, M. (2004). Neoplasms of the Reproductive Tract: The Role of Hormone Exposure. ILAR, 45, 179-188.

44. Gambacciani, M., Ciaponi, M., Cappagli, B., Piaggesi, L., De Simone, L., Orlandi, R., et al. (1997). Body weight, body fat distribution, and hormonal replacement therapy in early postmenopausal women. Journal of Clinical Endocrinology and Metabolism, 82, 414-417.

45. Wade, G. N., \& Gray, J. M. (1979). Gonadal effects on food intake and adiposity: a metabolic hypothesis. Physiology \& Behavior, 22, 583-593.

46. Turgeon, J. L., Carr, M. C., Maki, P. M., Mendelsohn, M. E., \& Wise, P. M. (2006). Complex actions of sex steroids in adipose tissue, the cardiovascular system, and brain: Insights from basic science and clinical studies. Endocrine Reviews, 27, 575-605.

47. Clarkson, T. B., \& Karas, R. H. (2007). Do the cardiovascular disease risks and benefits of oral versus transdermal estrogen therapy differ between perimenopausal and postmenopausal women? Menopause, 14, 963-967.

48. Manson, J. E., \& Bassuk, S. S. (2007). Invited commentary: hormone therapy and risk of coronary heart disease why renew the focus on the early years of menopause? American Journal of Epidemiology, 166, 511-517.

49. Pendaries, C., Darblade, B., Rochaix, P., Krust, A., Chambon, P., Korach, K. S., et al. (2002). The AF-1 activation-function of
ERalpha may be dispensable to mediate the effect of estradiol on endothelial NO production in mice. Proceedings of the National Academy of Sciences of the United States of America, 99, 22052210.

50. Kos, M., Denger, S., Reid, G., Korach, K. S., \& Gannon, F. (2002). Down but not out? A novel protein isoform of the estrogen receptor alpha is expressed in the estrogen receptor alpha knockout mouse. Journal of Molecular Endocrinology, 29, 281-286.

51. Dupont, S., Krust, A., Gansmuller, A., Dierich, A., Chambon, P., \& Mark, M. (2000). Effect of single and compound knockouts of estrogen receptors alpha (ERalpha) and beta (ERbeta) on mouse reproductive phenotypes. Development, 127, 4277-4291.

52. Sullivan, T. R., Jr., Karas, R. H., Aronovitz, M., Faller, G. T., Ziar, J. P., Smith, J. J., et al. (1995). Estrogen inhibits the response-toinjury in a mouse carotid artery model. Journal of Clinical Investigation, 96, 2482-2488.

53. Kuiper, G. G., van den Bemd, G. J., \& van Leeuwen, J. P. (1999). Estrogen receptor and the SERM concept. Journal of Endocrinological Investigation, 22, 594-603.

54. Christian, R. C., Liu, P. Y., Harrington, S., Ruan, M., Miller, V. M., \& Fitzpatrick, L. A. (2006). Intimal estrogen receptor (ER) beta, but not ERalpha expression, is correlated with coronary calcification and atherosclerosis in pre- and postmenopausal women. Journal of Clinical Endocrinology and Metabolism, 91, 2713-2720

55. Miller, H., Poon, S., Hibbert, B., Rayner, K., Chen, Y. X., \& O'Brien, E. R. (2005). Modulation of estrogen signaling by the novel interaction of heat shock protein 27, a biomarker for atherosclerosis, and estrogen receptor beta: mechanistic insight into the vascular effects of estrogens. Arteriosclerosis, Thrombosis, and Vascular Biology, 25, e10-14.

56. Leygue, E., Dotzlaw, H., Lu, B., Glor, C., Watson, P. H., \& Murphy, L. C. (1998). Estrogen receptor beta: mine is longer than yours? Journal of Clinical Endocrinology and Metabolism, 83, 3754-3755.

57. Dubey, R. K., Jackson, E. K., Gillespie, D. G., Zacharia, L. C., \& Imthurn, B. (2004). Catecholamines block the antimitogenic effect of estradiol on human coronary artery smooth muscle cells. Journal of Clinical Endocrinology and Metabolism, 89, 39223931.

58. Herrington, D. M., Howard, T. D., Brosnihan, K. B., McDonnell, D. P., Li, X., Hawkins, G. A., et al. (2002). Common estrogen receptor polymorphism augments effects of hormone replacement therapy on E-selectin but not C-reactive protein. Circulation, 105, $1879-1882$.

59. Herrington, D. M., Howard, T. D., Hawkins, G. A., Reboussin, D. M., Xu, J., Zheng, S. L., et al. (2002). Estrogen-receptor polymorphisms and effects of estrogen replacement on highdensity lipoprotein cholesterol in women with coronary disease. New England Journal of Medicine, 346, 967-974.

60. Hanke, H., Kamenz, J., Hanke, S., Spiess, J., Lenz, C., Brehme, U., et al. (1999). Effect of 17-beta estradiol on pre-existing atherosclerotic lesions: role of the endothelium. Atherosclerosis, 147, 123-132. 